
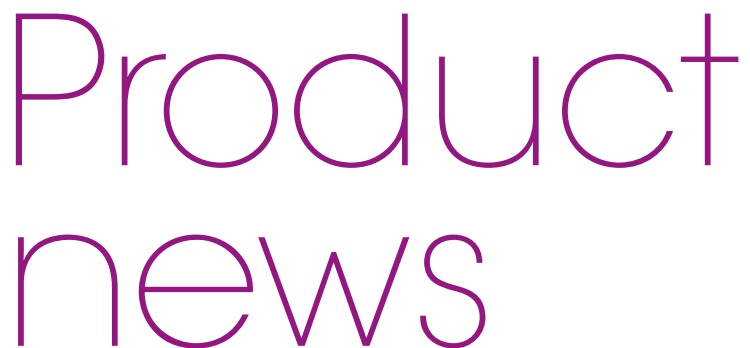

Product news is provided as a service to readers using text and images from the manufacturer, supplier or distributor and does not imply endorsement by BDJ Team. Normal and prudent research should be exercised before purchase

\section{EFFECTIVE RELIEF FROM HYPERSENSITIVITY}

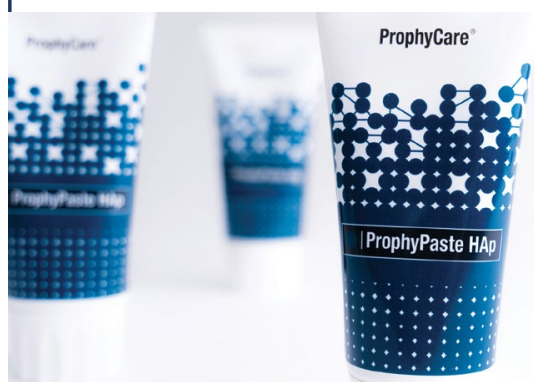

ProphyCare HAp is a new generation of prophy pastes with a unique composition including hydroxyapatite that effectively will block the open dentine tubules on an exposed dentine surface. The result is a barrier that will provide the patient with instant relief from hypersensitivity.

ProphyCare HAp is used for both stain removal and final polishing. It offers effective stain removal properties at the beginning of the treatment, then the abrasive effect gradually reduces, giving the paste its final polishing properties at the end of the treatment. Using the same paste for stain removal and final polishing offers decreased treatment time. It is fluoride and paraben free and studies have shown that products containing hydroxyapatite show better remineralising properties than traditional fluoride products. ProphyCare HAp's mild mint taste and appealing texture is pleasant for patients of all ages and does not splatter, liquify or separate and is easy to rinse-off.

For more information visit www. directadental.com.

\title{
NATURALLY ENHANCED RECOVERY
}

Invasive dental procedures can leave the oral cavity vulnerable to plaque build-up. You can help patients optimise their recovery from treatment by recommending 'Perio plus' Forte mouth rinse.
It contains the highest concentration of chlorhexidine from the 'Perio plus' product range for a highly effective result. Designed for short-term use, 'Perio plus' Forte combines the benefits of chlorhexidine with those of Citrox - a broadspectrum anti-microbial substance extracted from bitter oranges.

Citrox naturally enhances the effects of chlorhexidine to create a high-performance mouth rinse that protects the oral cavity, with minimal risk of irritation, discolouration and disruption to taste.

Discover the complete range of 'Perio plus' mouth rinses online today.

For more information call 01480862084, email info@ curaprox.co.uk or visit www. perioplus.com/uk.

\section{AFFORDABLE DISINFECTION MADE EASY}

Are you looking for a surface cleaner that effectively cleans even the toughest to reach spots of your practice?

AIRGENE CE Airborne

Surface Disinfectant from

Eschmann is a smart way

to help guarantee that indoor surfaces are properly disinfected. The unique one-shot technology forms a cloud of the product that covers an area of $40 \mathrm{~m}^{3}$ in under one hour, destroying $99.99 \%$ of bacteria and viruses, including Coronavirus, and neutralising odours caused by the decomposition of surface bacteria.

AIRGENE CE Airborne Surface Disinfectant is available to purchase on the Eschmann website as a single unit and in cases of 12 .

To find out more, contact Eschmann today.

For more information on the highly effective and affordable range of infection control products from Eschmann, visit www.eschmann.co.uk or call 01903 875787.

\section{ACHIEVE PERFECT} CLARITY AS YOU WORK

Pair your Carl Zeiss EyeMag dental loupes with the powerful EyeMag Light II to achieve perfect clarity as you work.

The EyeMag Light II delivers coaxial, daylight-quality illumination that is evenly distributed across the entire treatment site for a clear, unaltered view of tiny details and structures, with minimal shadow formation. It comes complete with two rechargeable battery packs that each offer up to eight hours of operation for a virtually interruption-free workflow.

With a swing-in image filter that prevents premature curing of composite materials, the EyeMag Light II is a must-have solution for your restorative armamentarium.

For more information call Nuview on 01453 872266, email info@nuview-ltd.com or visit www.nuview.co.uk. 